\title{
Adversity Quotient Siswa Madrasah Dalam Pemecahan Masalah Soal-Soal Hots Matematika
}

\author{
Samsul Hadi \\ samsulhadi@nusantaraglobal.ac.id \\ Program Studi Pendidikan Guru Sekolah Dasar, Institut Pendidikan Nusantara Global \\ Indonesia, 83511
}

\begin{abstract}
Abstrak. Pemecahan masalah soal-soal High Order Thinking Skill (HOTS) Matematika merupakan bagian proses pembelajaran matematika yang membutuhkan adversity quotient (AQ) siswa dalam level tinggi. Penelitian ini bertujuan untuk menganalisis level AQ siswa MA dalam memecahkan masalah soal-soal HOTS matematika. Penelitian ini menggunakan pendekatan kualitatif berbasis studi kasus. Partisipan penelitian terdiri dari 22 siswa kelas XI di salah satu MA di Lombok Timur, NTB, pada semester genap tahun akademik 2019-2020. Sampel penelitian ditentukan dengan purposive sampling. Instrumen yang digunakan berupa tes diagnostik terdiri atas soal uraian dan pilihan ganda, kuesioner $A Q$, dan pedoman wawancara. Hasil penelitian menunjukkan bahwa level AQ siswa MA berada pada kategori sedang dalam menyelesaikan soalsoal HOTS dan tidak ada keterkaitan antara tingkat kemampuan pemecahan masalah dan level AQ siswa dalam pembelajaran matematika.
\end{abstract}

Kata Kunci: Pemecahan Masalah, High Order Thinking Skill (HOTS), adversity quotient (AQ)

Abstract. Problem solving High Order Thinking Skill (HOTS) problems Mathematics is a part of the mathematics learning process that requires students at a high level of adversity quotient (AQ). This study aims to analyze the AQ level of MA students in solving HOTS math problems. This research uses a qualitative approach based on case studies. The study participants consisted of 22 students of class XI in one MA in East Lombok, NTB, in the even semester of the 2019-2020 academic year. The research sample was determined by purposive sampling. The instrument used in the form of a diagnostic test consists of question and multiple choice questions, $A Q$ questionnaire, and interview guidelines. The results showed that the AQ level of MA students was in the medium category in solving HOTS questions and there was no relationship between the level of problem solving ability and the AQ level of students in learning mathematics.

Keywords: Problem Solving, High Order Thinking Skill (HOTS), adversity quotient (AQ).

\section{PENDAHULUAN}

Pembelajaran matematika era revolusi industri 4.0 merupakan suatu bentuk pembelajaran matematika yang menekankan pada aspek keterampilan dalam berkarya dan pemecahan masalah. Dua aspek keterampilan tersebut juga merupakan bagian dari output pembelajaran matematika siswa di madrasah dalam kurikulum 2013. Oleh karena itu, setiap pembelajaran matematika guru diharapkan dapat memberikan suatu bentuk permasalahan matematika yang berkarakteristik soal-soal high order thinking skills (HOTS). Tujuannya adalah agar siswa terbiasa memecahkan soal-soal yang sulit dan membutuhkan pemahaman materi yang mendalam dan kreativitas penyelesaian yang baik dan inovatif. Selain itu, pemecahan masalah soal-soal HOTS matematika merupakan suatu strategi yang baik bagi guru dalam mengetahui daya juang siswa di madrasah dalam menyelesaikan soal-soal yang rumit dan kompleks. Pada dasarnya pemecahan masalah merupakan salah satu kompetensi pembelajaran matematika yang diharapkan tumbuh pada diri siswa, namun fakta di lapangan menunjukkan bahwa siswa masih kesulitan dalam menyelesaikan soal-soal HOTS dalam matematika. Hal ini dapat diketahui dari kutipan wawancara dengan salah satu siswa MA kelas XI di Lombok Timur sebagai berikut: 
Peneliti: Ketika guru memberikan soal-soal HOTS matematika untuk siswa, Apakah kamu bisa menyelesaikannya"

Siswa: Saya dan teman-teman masih kesulitan, kadang saya dan teman-teman tidak bisa, dan mudah nyerah"

Peneliti: Kenapa?

Siswa: Kami belum terbiasa dan tidak tahu cara penyelesaiannya. Kalaupun tahu caranya tapi suka stagnan sehingga tidak bisa diselesaikan.

Hasil-hasil riset terdahulu juga tidak jauh berbeda dengan fakta lapangan di atas yang menunjukkan rendahnya kemampuan pemecahan masalah matematis siswa SMA/MA dalam menyelesaikan soal-soal HOTS matematika. Berikut beberapa hasil riset tersebut, yaitu (1) Seifi, Haghverdi, \& Aziz Mohamadi (2012) bahwa siswa tidak mampu membuat representasi masalah, menyusun strategi, dan melaksanakan strategi tersebut; (2) Salemeh \& Etchells (2016) bahwa siswa kesulitan dalam memahami, menganalisis, dan menginterpretasikan masalah; dan (3) Jaenuri \& Riyadi (2017) bahwa siswa tidak mampu membuat model matematika dari masalah.

Rendahnya kemampuan siswa dalam menyelesaikan soal-soal HOTS dalam matematika bukan hanya dipengaruhi oleh kurangnya pemahaman konsep, keterampilan matematika, dan pengalaman siswa dalam memecahkan soal-soal HOTS melainkan dipengaruhi aspek psikologis dan kemampuan siswa dalam menghadapi kesulitan yang disebut adversity quotient (AQ) (Hidayat \& Sariningsih, 2018). Hasil kajian Leonard \& Amanah (2014) menunjukkan bahwa level AQ siswa berpengaruh besar pada level kemampuan berpikir kritis siswa dalam menghadapi permasalahan baik dalam kesulitan maupun kegagalan. Oleh karena itu, faktor AQ siswa perlu mendapat perhatian guru dalam setiap pembelajaran matematika agar siswa yang memiliki level AQ rendah dan sedang tidak mudah menyerah dalam menyelesaikan soalsoal HOTS matematika. Hal ini dikarenakan pada soal-soal HOTS matematika seringkali siswa mudah stress dan putus asa dalam proses pemecahan yang dipengaruhi oleh tingkat keberagaman kesukaran.
Berdasarkan uraian latar belakang di atas, penulis tertarik melakukan suatu kajian riset yang berjudul “Adversity Quotient Siswa Madrasah Dalam Pemecahan Masalah Soal-Soal HOTs Matematika". Topik permasalahan dalam penelitian ini dikaji dengan pendekatan penelitian kualitatif dengan batasan masalah pada konsep adversity quotient (AQ), kemampuan siswa madrasah pada pemecahan masalah soal-soal HOTS matematika dalam pembelajaran matematika. Rumusan masalah dalam penelitian ini adalah bagaimanakah level adversity quotient (AQ) siswa madrasah dalam pemecahan soal-soal HOTS Matematika pada pembelajaran matematika. Tujuan penelitian ini adalah untuk mengetahui gambaran level adversity quotient (AQ) siswa dalam pemecahan soal-soal HOTS matematika pada pembelajaran matematika.

\section{TINJAUAN TEORI}

Suatu soal matematika dikatakan soal HOTS jika soal tersebut ada tantangan (challenge) yang menuntut kreativitas dan keterampilan siswa dalam berpkir untuk membangun strategi penyelesaian yang tepat dan benar. Karakteristik soal-soal HOTS, yaitu (1) soal mengukur kemampuan dan keterampilan berpikir tingkat tinggi siswa; (2) soal tidak rutin; dan (3) soal berbasis permasalahan yang kontekstual (Widana, Adi, Herdiyanto, Abdi, Marsito, Istiqomah, 2019). Selain itu, soal-soal HOTS merupakan bagian dari konsep keterampilan berpikir yang dikembangkan berdasarkan model taksonomi Bloom. Level keterampilan berpikir taksonomi Bloom dapat dilihat pada gambar 1 di bawah ini (Febrian, 2018), yaitu:

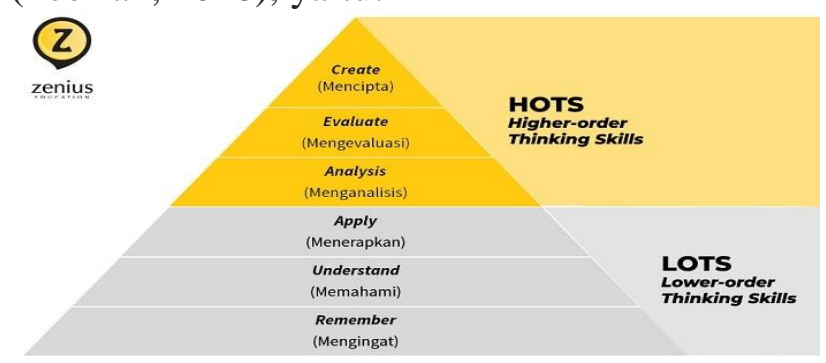

Gambar 1. Tingkat Keterampilan Berpikir

Taksonomi Bloom

Soal-soal HOTS pada dasarnya bagian dari pemecahan masalah. Krulik dan Rudnik (1995) mendefinisikan masalah secara formal 
sebagai berikut: "A problem is a situation, quantitatif or otherwise, that confront an individual or group of individual, that requires resolution, and for which the individual sees no apparent or obvius means or path to obtaining a solution." Definisi tersebut menjelaskan bahwa masalah adalah suatu situasi yang dihadapi oleh seseorang atau kelompok yang memerlukan suatu pemecahan tetapi individu atau kelompok tersebut tidak memiliki cara yang langsung dapat menentukan solusinya. Polya (1973) mengatakan bahwa masalah matematika ada dua jenis, yaitu (1) masalah menemukan (problem to find), masalah yang bertujuan menemukan, menentukan, atau memperoleh nilai suatu objek yang tidak dinyatakan dalam pertanyaan; dan (2) masalah membuktikan (problem to prove), masalah yang membutuhkan suatu prosedur dalam menunjukkan suatu pernyataan benar atau tidak.

Penyelesaian soal-soal HOTS tentu berbeda strategi pemecahan masalah yang digunakan dalam memperoleh jawaban dibanding penyelesaian soal-soal low order thinking skill (LOTS). Pemecahan masalah merupakan salah satu kemampuan yang harus dikembangkan dalam menyelesaikan soal HOTS matematika. Pemecahan masalah dipandang sebagai proses yang memberikan konteks antara konsep dan keterampilan siswa dibutuhkan yang dapat dikembangkan dari materi pembelajaran (Walle, 2008). Dalam penyelesaian soal HOTS kesedian siswa terlibat dalam suatu masalah sangat dibutuhkan karena siswa dapat mengembangkan diri menjadi pribadi yang konstruktif dan reflektif dalam menyelesaikan masalah. Selain itu, kemampuan siswa mengatasi soal HOTS dapat ditumbuhkan oleh guru melalui pembelajaran matematika yang mengembangkan aspek-aspek pemecahan masalah matematika siswa, adalah (1) membangun pengetahuan matematika melalui penyelesaian masalah (problem solving); (2) menerapkan dan menyesuaikan berbagai macam strategi yang tepat untuk menyelesaikan masalah; (3) mengamati dan mengembangkan proses penyelesaian masalah matematika; dan (4) menyelesaikan masalah matematika yang muncul dalam konteks lain (NCTM, 2000).
Dalam penyelesaian soal-soal HOTS terdapat beberapa aktivitas yang dilakukan siswa dalam memperoleh jawaban darisoal-soal tersebut. Tahapan aktivitas pemecahan masalah yang familiar digunakan dalam pembelajaran matematika yaitu tahapan Polya. Polya (1973) mengatakan bahwa ada empat tahapan aktivitas yang dilakukan, yaitu (1) memahami masalah (understand the problem), tahap ini diperlukan pemahaman siswa akan suatu masalah yang dihadapi dengan mengidentifikasi apa yang diketahui, apa yang ditanya, apa saja unsur yang ada, jumlah, hubungan, dan nilai-nilai yang terkait serta apa yang sedang mereka cari; (2) merencanakan pemecahan (devise a plan), tahap ini siswa mengidentifikasi operasi dan strategi apa saja yang terlibat dalam memecahkan masalah; (3) Melaksanakan rencana (carry out the plan), tahap ini apa yang dilakukan pada suatu tindakan didasarkan pada rencana yang telah dirancang; dan (4) memeriksa kembali (looking back), tahap ini siswa memeriksa kembali proses yang telah dilakukan selama pemecahan masalah.

Adversity Quotient (AQ)

Stolz (2005) bahwa kesuksesan siswa dalam suatu pekerjaan ditentukan adversity quotient (AQ) yang dimiliki. Keberhasilan siswa mengatasi kesulitan sangat ditentunkan faktor AQ siswa di madrasah. AQ merupakan intelejensi khusus yang berkaitan dengan kemampuan siswa dalam menghadapi kesulitan yang dihadapi (Suhartono, 2017). Dari urain definisi $\mathrm{AQ}$ di atas dapat disimpulkan bahwa AQ merupakan kecerdasan daya juang siswa dalam menghadapi dan mengatasi setiap kesulitan yang dihadapi dalam pembelajaran matematika. Hal ini berarti semakin tinggi AQ siswa akan berpengaruh positif terhadap keberhasilan siswa dalam menyelesaikan soalsoal HOTS.

Stolz (2005) bahwa ada tiga bentuk AQ, yaitu (1) AQ sebagai bentuk kerja konseptual yang baru dalam memahami dan meningkatkan jenis kesuksesan; (2) AQ sebagai bentuk ukuran dalam mengetahui respon terhadap kesulitan; dan (3) AQ sebagai bentuk peralatan dasar ilmiah dalam memperbaiki setiap respon terhadap kesulitan. Selain itu, Stolz (2005) juga mengidentifikasi individu menjadi 3 kelompok, 
yaitu: (1) quitter merupakan seseorang yang

\begin{tabular}{|l|l|}
\hline $\begin{array}{l}\text { Skor Adversity Quotient } \\
(\mathrm{AQ})(\mathrm{X})\end{array}$ & Klasifikasi \\
\hline $\mathrm{X}<(\mu-1,0 \sigma)$ & Rendah (quitter $)$ \\
\hline$(\mu-1,0 \sigma) \leq \mathrm{X}<(\mu+1,0 \sigma)$ & Sedang $($ camper $)$ \\
\hline$(\mu+1,0 \sigma)<\mathrm{X}$ & Tinggi (climber $)$ \\
\hline
\end{tabular}

berhenti di tengah jalan; (2) camper merupakan seseorang yang merasa puas pada posisi tertentu; dan (3) climber merupakan seseorang yang ingin terus meraih sukses.

Shivaranjani (2014) dan Stolz (2005) mengatakan bahwa AQ memiliki empat dimensi pokok, yaitu: (1) control (C), C berarti seberapa besar kendali yang dirasakan seseorang terhadap tantangan atau kesulitan dalam pekerjaan; (2) Origin and ownership (O2), $\mathrm{O} 2$ berarti bagaimana seseorang memandang sumber masalah dan berapa besar keterlibatannya dalam dalam mengatasi kesulitan; (3) Reach (R), R berarti sejauh mana kesulitan-kesulitan tersebut menjangkau bagian-bagian lain dari kehidupan seseorang; dan (4) Endurance (E), E berarti bagaimana daya tahan seseorang menghadapi masalah yang muncul dalam pekerjaan.

\section{METODE PENELITIA}

Penelitian ini merupakan penelitian kualitatif deskriptif. Penelitian dilaksanakan di salah satu MA Negeri di Lombok Timur dengan partisipan 29 siswa kelas XI yang terdiri dari 15 siswa laki-laki dan 14 siswa perempuan. Teknik pengambilan partisipan dengan teknik purposive sampling. Pengumpulan data dilakukan dengan tes da non tes. Tes dilakukan untuk mengukur kemampuan siswa dalam menyelesaikan soalsoal HOTS matematika dan non tes dilakukan dalam mengetahui tingkat adversity quotient (AQ) siswa.

Data yang diperoleh kemudian akan dianalisis baik dari data tes maupun non tes. Tujuan adalah untuk memperoleh gambaran AQ siswa dalam menyelesaikan soal-soal HOTS matematika. Dalam mengetahui level adversity quotient siswa, peneliti mengembangkan pedoman kuesioner profil respon adversity quotient (AQ) siswa berdasarkan indikator empat dimensi AQ. Kuesioner AQ menggunakan skala Likert, skala Likert digunakan dalam mengukur sikap, respon, dan persepsi seseorang atau sekelompok orang terhadap suatu fenomena sosial (Sugioyono, 2011). Menurut Azwar (2015), kriteria pengelompokkannya dapat dilihat pada tabel berikut:

Tabel 1. Kriteria Level Adversity Quotient (AQ) Siswa

Keterangan:

$\mu=$ Rata-rata skor AQ

$\sigma=$ Standar Deviasi skor AQ

Adapun komponen aktivitas analisis data dalam penelitian kualitatif ini, yaitu (1) data reduction, tahap ini peneliti mereduksi data temuan lapangan baik melalui test tertulis, kuesioner AQ, interview, observasi, dan studi dokumentasi; (2) data display, peneliti menyajikan data penelitian dalam bentuk data deskriptif terhadap kemampuan, kesulitankesulitan, pemikiran moderasi Islam, dan adversity quotient (AQ) siswa dalam menyelesaikan soal-soal HOTS matematika; dan (3) data conclusions: drawing/verifying, peneliti menggunakan hasil analisis pada penyajian data pada data display dalam membuat deskripsi kemampuan, kesulitankesulitan, pemikiran moderasi Islam, dan adversity quotient (AQ) siswa dalam menyelesaikan soal-soal HOTS matematika. Dalam uji keabsahan data atau temuan, peneliti menerapkan prosedur validasi, seperti triangulasi, member check, analisis kasus negatif, perpanjangan pengamatan, peningatan ketekunan, dan diskusi dengan teman sejawat (Sugioyono, 2011). Selain validasi data, peneliti juga akan melakukan uji triangulasi sumber data dan teknik pengumpulan data.

\section{HASIL DAN PEMBAHASAN}

Dalam tes pemecahan masalah soal HOTS matematika, dapat diketahui bahwa nilai tertinggi yang diperoleh siswa adalah 71 dan nilai terendah yang diperoleh adalah 8. Dari hasil tes uraian menunjukkan bahwa sebagian besar siswa masih kesulitan dalam menyelesaikan masalah soal-soal HOTs matematika. Dari 29 siswa dalam menyelesaikan 5 butir soal uraian dalam tes pemecahan masalah soal-soal HOTs matematika. Soal nomor 1, 5 siswa yang dapat menjawab dengan lengkap. Soal nomor 2, 4 
siswa yang dapat menjawab dengan lengkap. Soal nomor 3, hanya 1 siswa yang dapat menjawab dengan lengkap. Soal nomor 4, tidak ada siswa yang dapat menjawab dengan lengkap. Namun, soal nomor 4 hanya ada satu siswa yang dapat menyelesaikan soal dengan benar meskipun terdapat kekurangan informasi yang disebutkan pada saat menuliskan data yang diketahui dan data yang ditanyakan. Adapun soal nomor 5, ada 4 siswa yang dapat menjawab dengan lengkap. Hal ini berarti bahwa masih banyak siswa yang tidak dapat menjawab soal pemecahan masalah matematika dengan lengkap dan benar.

Gambaran hasil tes pilihan ganda pemecahan masalah soal-soal HOTs yang diberikan kepada siswa selaku partisipan dalam mendiagnosa kesulitan-kesulitan siswa dalam memecahkan masalah matematik dapat diketahui bahwa dari 12 soal pilihan yang dikerjakan siswa jumlah soal paling banyak yang dapat dijawab dengan benar adalah 11 soal. Hanya ada 2 siswa yang mampu menjawab 11 soal tersebut. Jumlah soal paling sedikit yang mampu dijawab dengan benar adalah 1 soal. Dari hasil studi dokumentasi dapat diketahui bahwa $70 \%$ siswa mengalami kesulitan dalam bahasa, 27\% siswa mengalami kesulitan dalam pemodelan, dan $40 \%$ siswa mengalami kesulitan dalam terapan.

Berkaitan dengan adversity quotient siswa, berikut hasil distribusi level AQ siswa dapat dilihat pada tabel di bawah ini:

Tabel 1. Level AQ Siswa

\begin{tabular}{|c|c|c|c|c|}
\hline No & Kriteria & Klasifikasi & $\mathrm{F}$ & $\%$ \\
\hline 1 & $\begin{array}{c}\mathrm{X} \\
<74.91443\end{array}$ & $\begin{array}{c}\text { Rendah } \\
(\text { Quitter })\end{array}$ & 5 & $17 \%$ \\
\hline 2 & $\begin{array}{c}74.91443 \leq \\
\mathrm{X} \\
<96.53385\end{array}$ & $\begin{array}{c}\text { Sedang } \\
\text { (Camper) }\end{array}$ & 18 & $62 \%$ \\
\hline 3 & $\begin{array}{c}96.53385< \\
\mathrm{X}\end{array}$ & $\begin{array}{c}\text { Tinggi } \\
(\text { Climber })\end{array}$ & 6 & $21 \%$ \\
\hline
\end{tabular}

Berdasarkan tabel di atas dapat diketahui bahwa level adversity quotient siswa berada pada kategori rendah $17 \%$, sedang $62 \%$, dan tinggi $21 \%$. Data ini dapat memberikan informasi yang cukup pada pihak madrasah khususnya guru dalam mengetahui level AQ siswa dalam pembelajaran matematika. Dari data ini juga dapat diketahui bahwa sebagian besar siswa MA memiliki level AQ kategori sedang (camper) sehingga data ini merepresentasikan bahwa siswa perlu mendapat perhatian, motivasi,dan bimbingan guru mengenai optimalisasi konsep pemikiran moderasi Islam agar siswa tidak mudah menyerah dan putus asa dalam menghadapi segala hambatan dalam pembelajaran matematika terutama ketika siswa menyelesaikan soal-soal HOTS matematika. Sebagian besar siswa kesulitan dalam aspek bahasa. Hal ini berarti siswa kesulitan dalam memahami, mengidentifikasi, dan menafsirkan masalah. Situasi ini menyebabkan siswa tidak dapat membuat representasi matematika dan strategi yang dapat digunakan dalam menyelesaikan masalah yang sedang dihadapi. Selain itu, ditemukan bahwa beberapa siswa yang memiliki kemampuan pemecahan masalah yang berbeda atau tidak selaras dalam menyelesaikan soal uraian dan pilihan ganda. Misalnya siswa $Z$, ketika menyelesaikan soal uraian siswa terindikasi kesulitan dalam aspek bahasa, pemodelan, dan terapan. Hal ini dikarenakan siswa hanya dapat menuliskan data yang diketahui dan ditanyakannya saja dalam lembar jawaban yang dikumpulkan tanpa dapat melakukan apa-apa seperti membuat strategi dan menjalankan strategi tersebut hingga memperoleh jawaban yang benar. Berbeda halnya pada tes pilihan ganda, $Z$ tidak terindikasi kesulitan dalam aspek pemodelan. Hal ini bisa terjadi karena siswa dalam menjawab soal pilihan ganda siswa sebagian besar menggunakan feeling, menebak dan logika selain menggunakan cara rumus atau strategi lainnya dalam proses perhitungan.

Berkaitan dengan adversity quotient siswa kelas MA, data AQ diperoleh dari hasil pengisian kuesioner yang sudah diisi oleh siswa. Dari hasil kuesioner AQ tersebut kemudian dianalisis dan dikelompokkan menjadi beberapa kategori yaitu rendah (quitter), sedang (camper), dan tinggi (climber).Pengelompokkan level AQ siswa pada dasarnya dilakukan dalam penyederhanaan analisis data temuan AQ siswa dalam menyelesaikan masalah matematika. Berdasarkan Tabel 1 dapat diketahui bahwa level adversity quotient siswa MA berada pada kategori rendah $17 \%$, sedang $62 \%$, dan tinggi 
$21 \%$. Data inidapat memberikan informasi yang cukup pada pihak sekolah khususnya guru dalam mengetahui level AQ siswa dalam pembelajaran matematika. Dari data ini juga dapat diketahui bahwa sebagian besar siswa kelas XI memiliki level AQ kategori sedang. Hal ini berarti siswa yang berada pada level AQ tinggi masih sedikit. Meskipun demikian, siswa pada level AQ rendah lebih sedikit dibandingkan siswa pada level AQ tinggi. Namun, data level AQ kategori sedang ini cukup merepresentasikan bahwa siswa perlu mendapat perhatian guru dan pihak lainnya di sekolah agar memberikan perhatian dan motivasi lebih kepada siswa dalam menghadapi segala tantangan dan kesulitan baik dalam pembelajaran maupun masalah lainnya di kehidupan sehari-hari. Tentu, keaktifan dan kreativitas siswa dalam hal ini lebih ditingkatkan agar tidak mudah menyerah dan putus asa dalam menghadapi situasi yang sulit di masa mendatang

Dari hasil kuesioner AQ dapat diketahui level dimensi AQ siswa kelas XI dalam pemecahan masalah soal-soal HOTS matematika dalam setiap dimensi sebagai berikut:

\section{a. Control (C)}

Proses analisis temuan data level control siswa pada hasil kuesioner dilakukan sama dengan analisis level AQ siswa dengan mengelompokkan level control siswa ke dalam tiga level yaitu level rendah, sedang, dan tinggi. Distribusi level control siswa dapat dilihat pada tabel di bawah ini:

Tabel 3. Level Control Siswa

\begin{tabular}{|c|c|c|c|c|}
\hline No & Kriteria & Klasifikasi & $\mathrm{F}$ & $\%$ \\
\hline 1 & $\begin{array}{c}\mathrm{X} \\
<18.2854\end{array}$ & $\begin{array}{c}\text { Rendah } \\
(\text { Quitter })\end{array}$ & 6 & $21 \%$ \\
\hline 2 & $\begin{array}{c}18.2854 \leq \\
\mathrm{X} \\
<24.33528\end{array}$ & $\begin{array}{c}\text { Sedang } \\
\text { (Camper) }\end{array}$ & 19 & $65 \%$ \\
\hline 3 & $\begin{array}{c}24.33528< \\
\mathrm{X}\end{array}$ & $\begin{array}{c}\text { Tinggi } \\
\text { (Climber) }\end{array}$ & 4 & $14 \%$ \\
\hline
\end{tabular}

Berdasarkan tabel di atas dapat diketahui bahwa level control siswa berada kategori rendah $21 \%$, sedang $65 \%$, dan tinggi $14 \%$. Data ini tentu memberikan informasi yang cukup kepada semua civitas sekolah sebagai bahan pertimbangan khususnya guru dalam mengetahui level kendali diri siswa dalam pembelajaran matematika. Meskipun persentase kendali diri siswa level sedang lebih besar daripada persentase level rendah dan tinggi. Namun, persentase kendali diri siswa pada level rendah lebih besar daripada persentase kendali diri siswa pada level tinggi. Hal ini mengindikasikan perlunya bimbingan guru dalam dalam mengontrol kendali diri siswa agar siswa tidak melakukan suatu aktivitas yang bisa merugikan dan mencelekakan diri mereka sendiri baik dalam aktivitas di dalam sekolah maupun di luar sekolah.

\section{b. Origin and Ownership $(\mathrm{O} 2)$}

Proses analisis temuan data level $\mathrm{O} 2$ siswa pada hasil kuesioner AQ dilakukan sama dengan analisis level AQ siswa dengan mengelompokkan level $\mathrm{O} 2$ siswa ke dalam tiga level yaitu level rendah, sedang, dan tinggi. Distribusi level O2 siswa dapat dilihat pada tabel di bawah berikut:

Tabel 4. Level O2 Siswa

\begin{tabular}{|c|c|c|c|c|}
\hline No & Kriteria & Klasifikasi & $\mathrm{F}$ & $\%$ \\
\hline 1 & $\begin{array}{c}\mathrm{X} \\
<20.83161\end{array}$ & $\begin{array}{c}\text { Rendah } \\
(\text { Quitter })\end{array}$ & 4 & $14 \%$ \\
\hline 2 & $\begin{array}{c}20.83161 \leq \\
\mathrm{X} \\
<26.27183\end{array}$ & $\begin{array}{c}\text { Sedang } \\
(\text { Camper })\end{array}$ & 20 & $69 \%$ \\
\hline 3 & $\begin{array}{c}26.27183< \\
\mathrm{X}\end{array}$ & $\begin{array}{c}\text { Tinggi } \\
(\text { Climber })\end{array}$ & 5 & $17 \%$ \\
\hline
\end{tabular}

Berdasarkan tabel di atas dapat diketahui bahwa level $\mathrm{O} 2$ siswa berada kategori rendah $14 \%$, sedang 69\%, dan tinggi 17\%. Data ini memberikan gambaran bahwa persentase level O2 pada kategori sedang lebih banyak dibandingkan persentase level $\mathrm{O} 2$ kategori rendah dan tinggi. Meskipun demikian, informasi ini cukup dijadikan masukan dan pertimbangan guru dalam memberikan konsep pemikiran moderasi Islam dan bimbingan baik dalam pembelajaran dan pembentukan karakter pengakuan diri yang baik dalam mengetahui sumber masalah dan mencari jalan keluar dari masalah yang dihadapi siswa dalam pembelajaran.

c. Reach $(\mathrm{R})$

Proses analisis temuan data level reach siswa pada hasil kuesioner AQ dilakukan sama dengan analisis level AQ siswa dengan mengelompokkan level reach siswa ke dalam 
tiga level yaitu level rendah, sedang, dan tinggi. Distribusi level reach siswa dapat dilihat pada tabel di bawah berikut:

Tabel 5. Level Reach Siswa

\begin{tabular}{|c|c|c|c|c|}
\hline No & Kriteria & Klasifikasi & $\mathrm{F}$ & $(\%)$ \\
\hline 1 & $\mathrm{X}<16.66441$ & $\begin{array}{c}\text { Rendah } \\
(\text { Quitter })\end{array}$ & 7 & $24 \%$ \\
\hline 2 & $\begin{array}{c}16.66441 \leq \mathrm{X} \\
<22.50802\end{array}$ & $\begin{array}{c}\text { Sedang } \\
\text { (Camper) }\end{array}$ & 19 & $66 \%$ \\
\hline 3 & $22.50802<\mathrm{X}$ & $\begin{array}{c}\text { Tinggi } \\
\text { (Climber) }\end{array}$ & 3 & $10 \%$ \\
\hline
\end{tabular}

Berdasarkan tabel di atas dapat diketahui bahwa level Reach Siswa berada pada ketegori rendah $24 \%$, sedang 66\%, dan tinggi $10 \%$. Data ini memberikan informasi bahwa persentase level reach siswa kategori tinggi lebih kecil dibandingkan persentase level reach siswa kategori rendah dan sedang. Hal ini berarti bahwa siswa sangat penting untuk diberikan motivasi dan bimbingan agar daya jangkuan siswa dalam pembelajaran lebih baik atau meningkat baik dalam hard skill dan soft skill dalam pembelajaran matematika.

d. Endurance (E)

Proses analisis temuan data level Endurance siswa pada hasil kuesioner AQ dilakukan sama dengan analisis level AQ siswa dengan mengelompokkan level Endurance siswa ke dalam tiga level yaitu level rendah, sedang, dan tinggi. Distribusi level Endurance siswa dapat dilihat pada tabel di bawah berikut:

Tabel 6. Level Endurance Siswa

\begin{tabular}{|c|c|c|c|c|}
\hline No & Kriteria & Klasifikasi & $\mathrm{F}$ & $(\%)$ \\
\hline 1 & $\begin{array}{c}\mathrm{X} \\
<16.84467\end{array}$ & $\begin{array}{c}\text { Rendah } \\
(\text { Quitter })\end{array}$ & 5 & $17 \%$ \\
\hline 2 & $\begin{array}{c}16.84467 \leq \\
\mathrm{X} \\
<25.70705\end{array}$ & $\begin{array}{c}\text { Sedang } \\
\text { (Camper) }\end{array}$ & 16 & $55 \%$ \\
\hline 3 & $\begin{array}{c}25.70705< \\
\mathrm{X}\end{array}$ & $\begin{array}{c}\text { Tinggi } \\
\text { (Climber) }\end{array}$ & 8 & $28 \%$ \\
\hline
\end{tabular}

Berdasarkan tabel di atas dapat diketahui bahwa level endurance siswa berada pada kategori rendah $17 \%$, sedang 55\%, dan tinggi 28\%. Data ini memberikan informasi bahwa level endurance siswa pada kategori tinggi lebih rendah daripada level siswa pada kategori sedang meskipun persentasenya masih lebih tinggi daripada siswa pada kategori rendah. Namun, terlihat bahwa selisih persentase level tinggi dan rendah tidak jauh berbeda. Hal berarti bahwa daya tahan siswa dalam menghadapi suatu tantangan atau kesulitan masih rendah sehingga bimbingan dan motivasi dari pihak sekolah khususnya guru diharapkan mampu memotivasi siswa bahwa siswa dapat mengatasi dan menemukan jalan keluar dari setiap permasalahan baik masalah yang mencakup dalam pembelajaran maupun masalah lainnya.

Berdasarkan level AQ dan dimensi AQ siswa kelas XI di atas diketahui bahwa $17 \%$ siswa termasuk kelompok AQ quitter, 62\% siswa AQ camper, dan $21 \%$ siswa AQ climber. Sebelum data temuan dianalisis peneliti mengira bahwa siswa yang termasuk level AQ rendah kemampuan pemecahan masalahnya juga rendah, siswa dengan level AQ sedang kemampuan pemecahan masalahnya juga sedang, dan siswa yang termasuk level AQ tinggi maka kemampuan pemecahan masalahnya juga tinggi. Namun, setelah data dari studi dokumentasi dianalisis dapat diketahui bahwa siswa yang level AQ tinggi belum tentu memiliki kemampuan pemecahan masalah tinggi juga atau siswa yang level AQ sedang belum tentu memiliki kemampuan pemecahan masalah sedang begitu juga siswa yang level AQ rendah belum tentu juga memiliki kemampuan pemecahan masalah matematika rendah. Hal ini ditunjukkan dari hasil interview dengan beberapa siswa dapat disimpulkan bahwa sebagian dari siswa suka dengan tantangan, namun tidak semua siswa mampu bertahan dalam menghadapi kesulitan dalam tantangan/masalah yang dihadapi. Hal ini disebabkan karena sebagian siswa tidak memiliki pengetahuan konsep, skill matematika, pengalaman, motivasi, dan percaya diri dengan baik.

\section{KESIMPULAN}

Berdasarkan hasil temuan dan pembahasan dalam penelitian ini dapat ditarik kesimpulan bahwa sebagian besar siswa mudah menyerah dan putus asa dalam menghadapi kesulitan dalam pemecahan soal-soal HOTS. Level AQ siswa tidak dapat dijadikan landasan dalam menentukan level kemampuan siswa dalam menyelesaikan masalah soal-soal HOTS matematika. Hal ini dikarenakan siswa yang 
mempunyai level AQ tinggi belum tentu mempunyai level kemampuan menyelesaikan masalah matematika pada level tinggi juga. Selain itu, siswa yang level AQ nya rendah belum tentu dimensi AQ nya rendah juga baik dimensi C, O2, R, dan E. Dalam level AQ siswa, level tiap dimensi C, O2, R, dan E bisa saja sama atau berbeda. Selain itu, siswa juga kesulitan dalam beberapa faktor yaitu faktor bahasa, konsep, dan terapan dalam menyelesaikan soal-soal HOTS Matematika.

\section{REKOMENDASI}

Beberapa rekomendasi bagi siswa, guru, dan peneliti selanjutnya, yaitu (1) Untuk siswa, hasil penelitian dapat dijadikan sebagai bahan refleksi diri dalam pembelajaran matematika agar dapat meningkatkan kompetensi pemecahan masalah matematika dan level adversity quotient dalam pembelajaran, (2) Untuk guru, hasil penelitian ini dapat dijadikan masukkan yang positif sebagai pemicu peningkatan kinerja dan kompetensi dalam pembelajaran dalam membantu siswa dalam peningkatan kemampuan pemecahan masalah dan level $A Q$ siswa dalam pembelajaran, dan (3) Untuk peneliti selanjutnya, hasil penelitian ini dapat dijadikan salah satu bahan kajian dalam penelitian selanjutnya baik mengenai topik yang sama dala pembelajaran matematika dengan pendekatan yang berbeda.

\section{DAFTAR PUSTAKA}

Azwar, S. (2013). Penyusunan Skala Psikologi. Yogyakarta: Pustaka Pelajar

Febrian, R. (2018). Soal-soal HOTS yang Bikin Siswa Pusing Itu. https://tirto.id/soalsoal-hots-yang-bikin-siswa-pusing-itupenting-cStV. Diakses pada tanggal 3 Agustus 2019 pukul 08.00 WITA.

Hidayat, W \& Sariningsih , R. (2018). Kemampuan Pemecahan Masalah Matematis Dan Adversity Quotient Siswa Smp Melalui Pembelajaran Open Ended. Jurnal Nasional Pendidikan Matematika, Vol. 2, No. 1, ISSN: 25494937.

Jaenuri, M \& Riyadi, S. (2017). Eksperimentasi Model Sinektik Terhadap Kemampuan Pemecahan Masalah Matematisdan Self
Efficacy Siswa. Edumatica, Volume 07, Nomor 02, Oktober 2017, ISSN: 20882157.

Krulik, Stephen dan Rudnick, Jesse A. (1995).

The New Source book for Teaching Reasoning and Problem Solving in Elementary School. Boston : Temple University.

Leonard \& Amanah, N. (2014). Pengaruh Adversity Quotient (AQ) dan Kemampuan Berpikir Kritis Terhadap Prestasi Belajar Matematika. Perspektif Ilmu Pendidikan, Vol. 28 No.1 April 2014.

Polya, G. (1973). How to solve It. New Jersey: Princeton University Press.

Salemeh, Z \& Etchells, M. J. (2016). A Case Study: Sources of Difficulties in Solving Word Problems in an International Private School. EIJEAS (Electronic International Journal of Education, Arts, and Science), Volume:2, Issue: Special Issue, 149-163.

Seifi, M., Haghverdi, M.,\&Azizmohamadi, F. (2012).Recognition of Students' Difficulties in Solving Mathematical Word Problems from the Viewpoint of Teachers. Journal of Basic and Applied Scientific Research (J. Basic. Appl. Sci. Res), 2(3), 2923-2928, ISSN 2090-4304.

Shivaranjani. (2014). Adversity Quotient: One Stop Solution to Combat Attrition Rate of Women in Indian It Sector. IJBARR, Vol. 1, Issue. 5, page 181.

Stolz, P, G. (2005). Adversity Quotient: Mengubah Hambatan Menjadi Peluang. Jakarta: PT Grasindo. 